\title{
ANALISIS FORMULASI INSTRUMEN SIMPLIFIKASI REGULASI MENUJU TATANAN HUKUM YANG TERINTEGRASI DAN HARMONIS
}

\author{
Ahmad Sururi \\ Program Studi Administrasi Negara Fisip dan Hukum \\ Email : ahmadbroer@gmail.com
}

\begin{abstract}
Abstrak
Problem regulasi di Indonesia seperti kualitas yang masih buruk dari segi konten dan substansi, kuantitas regulasi yang tidak terkontrol, tidak adanya kewenangan atau otoritas tunggal pengelola regulasi dan kurangnya pemahaman menjadi penyebab terjadinya disharmonisasi regulasi. Tujuan penelitian ini adalah mendeskipsikan dan menganalisis bagaimana formulasi Instrumen Simplikasi Regulasi (ISR) menuju tatanan hukum yang terintegrasi dan harmonis. Metode penelitian yang digunakan adalah penelitian dengan menggunakan pendekatan kualitatif. Teknik yang digunakan adalah survei literatur akademis guna memperoleh konsep-konsep dan teori dengan kajian peraturan perundang-undangan. Teknik pengumpulan data melalui penelusuran berbagai sumber dan literatur yang relevan dengan penelitian yaitu dokumen resmi yang dikeluarkan oleh pemerintah seperti peraturan perundang-undangan, pemberitaan media massa cetak dan elektronik, jurnal dengan pendekatan hukum normatif dan buku-buku atau referensi yang terkait dengan regulasi. Proses analisis dilakukan secara komprehensif dengan tujuan agar hasil intrepretatif dan analisis tersebut bersifat deskriptif analitis. Hasil penelitian dan pembahasan diperoleh bahwa reformasi regulasi melalui instrumen simplifikasi regulasi merupakan salah satu opsi yang tepat dalam rangka menciptakan tatanan regulasi yang tertib dan harmonis. Capaian simplifikasi regulasi sejalan dengan arah kebijakan pembangunan bidang regulasi 2015-2019 yaitu mewujudkan sinergitas antara kebijakan dan regulasi agar tercipta sistem regulasi nasional yang sederhana dan tertib dalam rangka mendukung pembangunan keunggulan komparatif perekonomian yang berbasis sumber daya alam yang tersedia, sumber daya manusia yang berkualitas serta kemampuan Iptek sehingga simplifikasi regulasi sebagai instrumen reformasi regulasi dapat terwujud secara ideal dalam mendukung proses pembangunan bidang regulasi secara nasional.
\end{abstract}

Kata kunci : Instrumen Simplifikasi Regulasi, tatanan Hukum tertib dan harmonis.

\section{PENDAHULUAN}

Di dalam penyelenggaraan negara, regulasi adalah instrumen untuk merealisasikan kebijakan-kebijakan negara dalam rangka mencapai tujuan bernegara. Sebagai instrumen untuk merealisasikan setiap kebijakan negara, maka regulasi harus dibentuk dengan cara yang benar sehingga mampu menghasilkan regulasi yang baik dan mampu mendorong terselenggaranya dinamika sosial yang tertib serta mampu mendorong kinerja penyelenggaraan negara (Strategi Nasional Reformasi Regulasi 2015-
2025) secara positif dan mendorong perilaku taat hukum bagi masyarakat. Jika demikian, maka sebuah regulasi yang direncanakan dan telah dilaksanakan akan memiliki dampak harmonisasi regulasi. Regulasi berupa Peraturan Daerah sebagai jenis peraturan perundang-undangan memiliki landasan konstitusional dan yuridis yang diatur kedudukannya dalam Undang-undang Dasar (UUD) 1945 pasal 18 ayat 6, UU Nomor 32 Tahun 2004 tentang Pemerintahan Daerah dan UU Nomor 12 Tahun 2011 tentang Pembentukan Peraturan Perundang-undangan. 
Selanjutnya berdasarkan Undang-undang Nomor 12 Tahun 2011 tentang Pembentukan Peraturan Perundang-undangan disebutkan bahwa pembentukan regulasi atau peraturan perundang-undangan yang dalam hal ini adalah Peraturan Daerah Provinsi dilaksanakan dengan cara dan metode yang pasti, baku dan standar. Didefinisikan dalam Undang-undang tersebut, Perda Provinsi adalah peraturan perundang-undangan yang dibentuk oleh Dewan Perwakilan Rakyat Daerah (DPRD) Provinsi dengan persetujuan bersama gubernur. Kolaborasi antara DPRD dan Gubernur sebagai regulator dalam pembentukan regulasi Peraturan Daerah merupakan salah satu bentuk tanggung jawab dan kewajiban dalam mewujudkan daerah sebagai wilayah hukum dalam mendukung pembangunan hukum nasional yang dilakukan secara terencana, terpadu dan berkelanjutan dalam sistem hukum nasional yang menjamin perlindungan hak dan kewajiban warga negara.

Dalam sistem hukum nasional yang mengintegrasikan regulasi berupa Peraturan Daerah dengan peraturan perundangundangan lainnya, maka Pemerintah Pusat melalui reformasi regulasi menitikberatkan prinsip-prinsip yang harus dipenuhi sebagai syarat sebuah regulasi yaitu harus mensejahterakan masyarakat, adanya analisis dampak dan biaya (inefisiensi) yang timbul dan regulasi dibuat sebagai pilihan tindakan terakhir setelah semua tindakan yang bersifat non reglatory tidak ada lagi. (Kedeputian Politik, hukum, Pertahanan dan Keamanan, serial Multilateral Meeting II, 2016). Kewenangan pemerintah pusat dalam melakukan pembinaan dan pengawasan terhadap pelaksanaan regulasi di daerah sebagaimana diamanatkan dalam pasal 218 ayat 1 UU Nomor 32 Tahun 2004 tentang Pemerintah Daerah.

Sejak kurun waktu tahun 2000 s/d 2015, pemerintah dan DPR sudah menghasilkan 12.471 regulasi. Sebaran regulasi tersebut terdiri dari UU (504), Perppu (27), Peraturan Pemerintah (1.386), Perpres (1.129), Keppres
(977), Inpres (137), dan Permen (8.331). Kategori dari seluruh regulasi mayoritas adalah sektor kehutanan (1585), jenis pajak (1.061), pertanian, perkebunan dan peternakan (753), perindustrian (411), kelautan dan perikanan (385), perdagangan (276), tata kelola birokrasi dan pelayanan publik (136), tata cara penanaman modal (92), dan persaingan usaha (43). Banyaknya regulasi tersebut ternyata tidak memberikan faktor dampak kualitas regulasi seperti yang diharapkan, disisi lain proses pengujian uji regulasi melalui lembaga kekuasaan kehakiman masih terjadi sampai dengan saat ini.

Masih banyaknya regulasi yang tumpang tindih dan berpotensi konflik antar pemangku kebijakan dan berdampak terhadap kepentingan publik merupakan beberapa fakta dari berbagai permasalahan regulasi yang disusun dengan cara yang tidak benar dan tidak sesuai dengan peraturan pembentukan peraturan perundang-undangan. Menurut Menkumham Yasonna Hamonangan Laoly ada tiga tantangan pengelolaan regulasi di Indonesia sebagai negara hukum saat ini yaitu : pertama, 'obesitas' regulasi di tingkat pusat dan daerah yang cenderung menghambat pembangunan ekonomi khususnya investasi swasta. Terlalu banyaknya jumlah regulasi ikut menghambat efektivitas pelayanan publik : kedua, disharmoni produk regulasi antar instansi tingkat pusat: ketiga, disharmoni produk regulasi antara instansi tingkat pusat dengan daerah baik substansi maupun teknik penyusunannya.

http://www.hukumonline.com. (Diakses pada tanggal 13 November 2017. Disharmonis atau permasalahan regulasi di Indonesia seperti kualitas yang masih buruk dari segi konten dan substansi, kuantitas regulasi yang tidak terkontrol, tidak adanya kewenangan atau otoritas tunggal pengelola regulasi dan kurangnya pemahaman merupakan beberapa problem regulasi yang terjadi.

Fenomena disharmonis regulasi tersebut menyebabkan pemerintah pusat dalam hal ini Kementerian Dalam Negeri melakukan 
pencabutan/revisi 3.143 regulasi yang terdiri dari Peraturan dan Keputusan Menteri Dalam Negeri serta Peraturan Daerah yang bertentangan dengan peraturan yang lebih tinggi, kepetingan umum, dan/atau kesusilaan serta menghambat investasi. Sedangkan Kementerian Koordinator Bidang Perekonomian (Menko) telah melakukan 204 deregulasi melalui sejumlah paket kebijakan meliputi pencabutan, revisi, dan pembentukan regulasi baru. Pembatalan, pencabutan dan revisi regulasi tersebut juga terdapat dibeberapa daerah seperti Sumatera Utara sebanyak 127 Perda/Perkada, Jawa Barat sebanyak 133 Perda/Perkada, Jawa Tengah sebanyak 118 Perda/Perkada dan Provinsi Banten yang sejak dalam kurun waktu tahun 2007 sampai dengan tahun 2016 sudah sebanyak 45 (Empat Puluh Lima) Peraturan Daerah (Perda) dan Peraturan Kepala Daerah (Perkada) di Provinsi Banten yang telah dibatalkan oleh Kementerian Dalam Negeri dengan rincian pada tahun 2007 terdapat 6 (enam) Perda dan Perkada yang telah dicabut, pada tahun 2008 terdapat 1 (satu) Perda dan Perkada, kemudian pada tahun 2009 sebanyak 2 (dua) Perda dan perkada dan pada tahun 2016 sebanyak 36 (tiga puluh enam) Perda dan Perkada yang telah dicabut. Sampai dengan tahun 2016, Peraturan Daerah yang masih berlaku di Provinsi Banten adalah 133 Peraturan Daerah.

Dengan uraian fakta dan permasalahan tersebut di atas, maka dalam mewujudkan kepastian dan tata kelola hukum yang berkeadilan dan memenuhi kepentingan publik maka salah satu upaya yang perlu didorong guna menciptakan tatanan hukum yang harmonis dan terintegrasi adalah adanya instrumen simplifikasi regulasi. Hal tersebut dapat dilakukan apabila tata cara penyusunan Peraturan daerah baik peraturan daerah provinsi maupun kabupaten/kota dilakukan dengan menggunakan metode yang tepat dan tidak bertentangan dengan peraturan perundangan yang lebih tinggi, kepentingan umum dan kesusilaan.
Konsep simplifikasi regulasi yang dilakukan oleh Badan Perencanaan Pembangunan Nasional (Bappenas) selaku leading sector meliputi "Self assessment, yaitu pelaksanaan simplifikasi regulasi berdasarkan target yang ditentukan oleh Kementrian/Lembaga (K/L) berdasarkan tema yang disepakati dengan Bappenas dan Peer Assesment yaitu pelaksanaan simplifikasi regulasi dengan mengakomodasi masukan dari berbagai pihak, termasuk K/L terkait, organisasi profesi, dunia usaha, pakar. Tujuan penelitian ini adalah mendeskipsikan dan menganalisis bagaimana formulasi Instrumen Simplikasi Regulasi (ISR) menuju tatanan hukum yang terintegrasi dan harmonis.

\section{KERANGKA KONSEPTUAL}

Menurut Kamus besar Bahasa Indonesia, regulasi adalah pengaturan. Menurut pasal 1 ayat 2 Undang-undang Nomor 12 tahun 2011 tentang Pembentukan Peraturan Peundangundangan disebutkan bahwa regulasi memiliki unsur-unsur peraturan tertulis, memuat norma hukum yang mengikat secara umum, dibentuk atau ditetapkan oleh lembaga negara atau pejabat yang berwenang dan disusun melalui prosedur tertentu yang telah ditentukan. Selanjutnya pakar hukum Logeman mengemukakan bahwa negara sebagai organisasi kekuasaan pada hakikatnya merupakan suatu tata kerjasama untuk membuat suatu kelompok manusia dapat berbuat atau bersikap sesuai dengan kehendak negara itu. Dengan demikian dapat disimpulkan bahwa negara mempunyai otoritas tertinggi sebagai organisasi yang berkuasa untuk memerintahkan anggota kelompok yang berada didalam negara tersebut untuk membuat regulasi agar tercipta kerjasama dan perilaku sosial yang sesuai dengan keinginan negara. Menurut The Organization for Economic Co-Operation and Development (OECD) dalam KPPOD (2013:1), disebutkan bahwa regulasi didefinisikan sebagai "berbagai kelompok instrumen yang digunakan oleh pemerintah 
untuk menetapkan aturan-aturan tertentu kepada perusahaan dan warga negara. Regulasi mencakup undang-undang, keputusan dan peraturan tingkat-bawah yang dikeluarkan oleh semua tingkatan pemerintah, dan peraturan yang dikeluarkan oleh lembaga non-governmental dan lembaga selfregulatory yang telah diberi kewenangan oleh pemerintah.

Terkait dengan konteks penelitian ini, regulasi berupa peraturan daerah menurut Jimly Asshiddiqie menyatakan bahwa Perda sejatinya tak pernah dianggap berbeda dengan produk UU yang dibuat oleh pusat, yang membedakan diantara keduanya bukanlah materi muatan ataupun isi, akan tetapi ruang lingkup keberlakuan dari masingmasing produk perundang-undangan tersebut, istilah Perda sendiri dapat dimaknai UU lokal (locale statue/locale wet) yaitu UndangUndang yang bersifat lokal. (Jimly Asshiddiqie, 2010 : 63).

Menurut penelitian yang dikemukakan oleh Ibnu Sina Candranegara (2017) dikemukakan bahwa pembentukan hukum haruslah membuat ketertiban bukan menciptakan inefisiensi hanya dikarenakan ego sektoral yang cenderung melemahkan orotitas hukum itu sendiri. Dengan demikian dapat disimpulkan bahwa efisiensi merupakan salah satu tujuan pembentukan hukum guna menciptakan otoritas hukum yang berdaulat. Sedangkan Minolah (2011) dalam penelitiannya mengemukakan bahwa Kewenangan pengujian peraturan daerah Provinsi di Indonesia saat ini dilakukan lewat dua model kewenangan, yaitu judicial review oleh Mahkamah Agung dan executive review oleh Pemerintah c.q Kementrian Dalam Negeri. Tata kelola regulasi melalui instrumen simplikasi regulasi dilakukan dengan cara menginventarisasi regulasi yang ada, mengidentifikasi masalah dan pemangku kepentingannya, melakukan evaluasi regulasi yang bermasalah dan mencabut yang tidak perlu (Kementrian Hukum dan HAM, 2016)

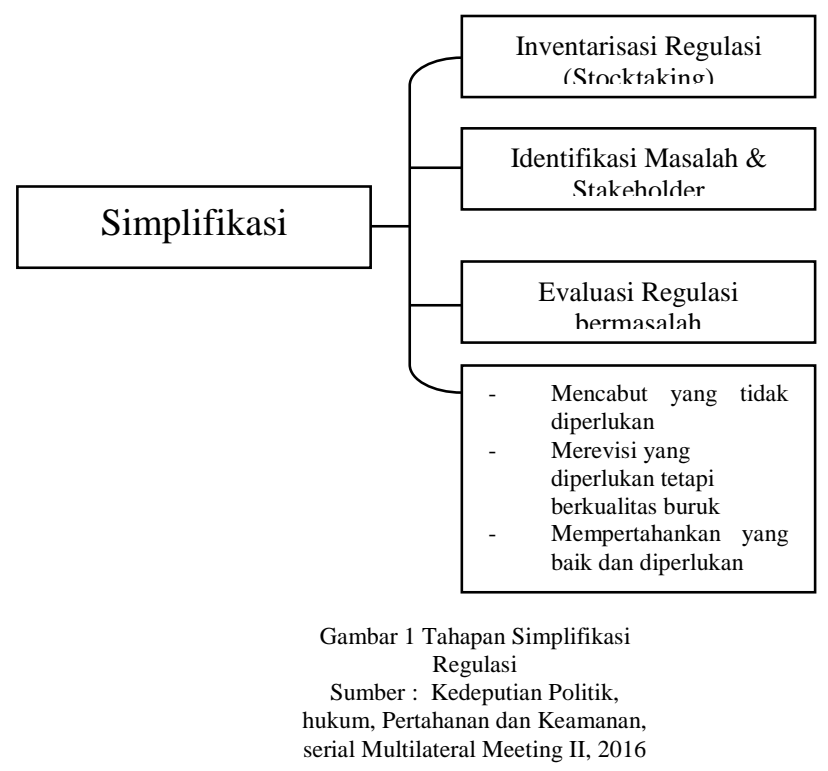

\section{METODE PENELITIAN}

Penelitian ini menggunakan pendekatan kualitatif. Teknik yang digunakan adalah survei literatur akademis guna memperoleh konsep-konsep dan teori dengan kajian peraturan perundang-undangan. Teknik pengumpulan data melalui penelusuran berbagai sumber dan literatur yang relevan dengan penelitian yaitu dokumen resmi yang dikeluarkan oleh pemerintah seperti peraturan perundang-undangan, pemberitaan media massa cetak dan elektronik, jurnal dengan pendekatan hukum normatif dan buku-buku atau referensi yang terkait dengan regulasi. Hal ini dimaksudkan untuk mendapatkan kerangka teori untuk kemudian dilihat relevansinya dengan berbagai fakta yang terjadi di lapangan.

Selanjutnya data-data tersebut disusun dalam suatu deskripsi dan dianalisis secara kualitatif dengan berpedoman kepada normanorma yang ada. Proses analisis dilakukan secara komprehensif dengan tujuan agar hasil intrepretatif dan analisis tersebut bersifat deskriptif analitis. 


\section{HASIL} PEMBAHASAN

PENELITIAN

DAN

\section{Tinjauan Yuridis Peraturan Daerah}

Dalam penjelasan UU Nomor 32 Tahun
2004 tentang Pemerintahan Daerah
dikemukakan bahwa pengawasan yang
dilaksanakan oleh Pemerintah terkait dengan
penyelenggaraan urusan pemerintahan dan
utamanya terhadap peraturan daerah dan
peraturan kepala daerah. Dalam hal pengawasan terhadap rancangan peraturan daerah dan peraturan daerah Pemerintah melakukan dengan 2 (dua) cara sebagai berikut: 1).Pengawasan terhadap rancangan peraturan daerah (RAPERDA), yaitu terhadap rancangan peraturan daerah yang mengatur pajak daerah, retribusi daerah, APBD, dan RUTR sebelum disahkan oleh kepala daerah terlebih dahulu dievaluasi oleh Menteri, Dalam Negeri untuk Raperda provinsi, dan oleh Gubernur terhadap Raperda kabupaten/kota. Mekanisme ini dilakukan agar pengaturan tentang hal-hal tersebut dapat mencapai daya guna dan hasil guna yang optimal. 2).Pengawasan terhadap semua peraturan -daerah di luar yang termasuk dalam angka 1, yaitu setiap peraturan daerah wajib disampaikan kepada Menteri Dalam Negeri untuk provinsi dan Gubernur untuk kabupaten/kota untuk memperoleh klarifikasi. Selanjutnya disebutkan terhadap peraturan daerah yang bertentangan dengan kepentingan umum dan peraturan yang lebih tinggi dapat dibatalkan sesuai mekanisme yang berlaku.

Dengan demikian secara substansial normatif, fungsi pengawasan dari pemerintah terhadap peraturan daerah sudah diamanatkan dalam UU Nomor 32 tahun 2004. Instrumen pengawasan pemerintah tersebut bersifat melekat sebagai bagian dari fungsi pengendalian kinerja sebuah peraturan daerah. Menurut Lyndal F. Urwick, pengawasan adalah upaya agar sesuatu dilaksanakan sesuai dengan peraturan yang telah ditetapkan dan instruksi yang dikeluarkan. Dikutip dari www.negarahukum. Artikel Damang, SH, MH (diakses pada tanggal 15 November
2017). Sehingga dapat disimpulkan negara dalam hal ini pemerintah sudah melakukan instrumen pengawasan sesuai dengan norma yang berlaku. Kepastian bahwa peraturan daerah harus memenuhi syarat-syarat tertentu menjadi argumentasi penting dalam UU Nomor 32 Tahun 2004 oleh sebab itu feed back dari penyelenggara daerah berupa pelaporan dan klaifikasi kepada pemerintah pusat yang dalam hal ini adalah Menteri Dalam Negeri perlu terus dilakukan.

Optimalisasi fungsi pembinaan dan pengawasan yang dilakukan oleh Pemerintah dengan menerapkan sanksi kepada penyelenggara pemerintahan daerah dapat dilakukan apabila ditemukan adanya fakta penyimpangan dan pelanggaran. Sanksi tersebut dapat berupa penataan kembali suatu daerah otonom, pembatalan pengangkatan pejabat, penangguhan dan pembatalan berlakunya suatu kebijakan daerah baik peraturan daerah, keputusan kepala daerah, dan ketentuan lain yang ditetapkan daerah serta dapat memberikan sanksi pidana yang diproses sesuai dengan peraturan perundangundangan.

Berdasarkan Pasal 137 UU Nomor 32 Tahun 2004 tentang Pemerintahan Daerah disebutkan bahwa perda dibentuk berdasarkan asas-asas pembentukan peraturan perundangundangan yang meliputi a).kejelasan tujuan; b).kelembagaan atau organ pembentuk yang tepat; c).kesesuaian antara jenis dan materi muatan; d).dapat dilaksanakan; e).kedayagunaan dan kehasilgunaan; f).kejelasan rumusan; dan g).keterbukaan. kemudian dalam Pasal 138 dikemukakan bahwa materi Peraturan daerah harus mengandung asas : 1).pengayoman; 2).kemanusiaan; 3).kebangsaan; 4).kekeluargaan; 5).kenusantaraan; 6).bhineka tunggal ika; 7).keadilan; 8).kesamaan kedudukan dalam hukum dan pemerintahan; 9).ketertiban dan kepastian hukum; dan/atau 10).keseimbangan, keserasian, dan keselarasan.

Pada tahap evaluasi, sesungguhnya proses evaluasi peraturan daerah sudah dilakukan 
sejak peraturan daerah masih berupa rancangan, hal tersebut dapat dilihat dalam pasal 144 UU Nomor 32 Tahun 2004 yang menyebutkan bahwa (1). Rancangan Perda yang telah disetujui bersama oleh DPRD dan Gubernur atau Bupati/Walikota disampaikan oleh pimpinan DPRD kepada Gubernur atau Bupati/Walikota untuk ditetapkan sebagal Perda; (2).Penyampaian rancangan Perda sebagaimana dimaksud pada ayat 1 dilakukan dalam jangka waktu paling lama 7 (tujuh) hari terhitung sejak tanggal persetujuan bersama; (3).Rancangan Perda sebagaimana dimaksud pada ayat 1 dan ayat 2 ditetapkan oleh Gubernur atau Bupati/Walikota paling lama 30 (tiga puluh) hari sejak rancangan tersebut disetujui bersama; (4).Dalam hal rancangan Perda tidak ditetapkan Gubernur atau Bupati/Walikota dalam waktu sebagaimana dimaksud pada ayat (3) rancangan Perda tersebut sah menjadi Perda dan wajib diundangkan dengan memuatnya dalam lembaran daerah; (5).Dalam hal sahnya rancangan Perda sebagaimana dimaksud pada ayat 4, rumusan kalimat pengesahannya berbunyi, "Perda ini dinyatakan sah," dengan mencantumkan tanggal sahnya. (6).Kalimat pengesahan sebagaimana dimaksud pada ayat (5) harus dibubuhkan pada halaman terakhir Perda sebelum pengundangan naskah Perda ke dalam lembaran daerah.

Tahap ekesekusi atau pengambilan keputusan mengenai regulasi secara yuridis normatif Mendagri memiliki keabsahan dalam pembatalan Perda karena berpayung hukum pada Pasal 251 Undang-Undang Nomor 23 Tahun 2014 tentang Pemerintah Daerah. Akan tetapi, jika melihat berdasarkan kewenangan, Mendagri bukanlah lembaga yang tepat dalam melakukan pembatalan perda, karena kewenangan dalam pembatalan perda telah diberikan oleh UUD NRI 1945 kepada Mahkamah Agung melalui Pasal 24A UUD NRI 1945. (Maharani Sukma, 2017).

Selanjutnya Jimly Asshiddiqie dalam Minolah (2011) menyatakan, bahwa:

"Perda sebagai hasil kerja Kepala Daerah dan Dewan Perwakilan Rakyat
Daerah (DPRD) tidak dapat dibatalkan oleh keputusan sepihak dari pemerintah pusat begitu saja." Lebih lanjut Jimly Asshiddiqie berpendapat, bahwa: Pemerintah pusat sudah seharusnya tidak diberi wewenang oleh undang-undang untuk mencabut perda sebagaimana diatur oleh Undang-Undang Nomor 32 Tahun 2004 Tentang Pemerintahan Daerah, tetapi yang berwenang menguji perda adalah Mahkamah Agung sebagaimana ketentuan Pasal 24A ayat (1) Undang-Undang Dasar 1945. Dalam Undang-Undang Nomor 32 Tahun 2004, prinsip otonomi daerah yang digunakan adalah prinsip otonomi seluas-luasnya dalam arti daerah diberikan kewenangan mengurus dan mengatur semua urusan pemerintah di luar yang menjadi urusan pemerintah yang ditetapkan dalam Undang-Undang ini. Daerah memiliki kewenangan membuat kebijakan daerah untuk memberi pelayanan, peningkatan peran serta, prakarsa, dan pemberdayaan masyarakat yang bertujuan pada peningkatan kesejahteraan rakyat.

Selanjutnya dalam Pasal 145 dikemukakan bahwa Perda disampaikan kepada Pemerintah paling lama 7 (tujuh) hari setelah ditetapkan. 1).Perda sebagaimana dimaksud pada ayat (1) yang bertentangan dengan, kepentingan umum dan/atau peraturan perundang-undangan yang lebih tinggi dapat dibatalkan oleh Pemerintah. Keputusan pembatalan Perda sebagaimana dimaksud pada ayat (2) ditetapkan dengan Peraturan Presiden paling lama 60 (enam puluh) hari sejak diterimanya Perda sebagaimana dimaksud pada ayat (1). (4) Paling lama 7 (tujuh) hari setelah keputusan pembatalan sebagaimana dimaksud pada ayat (3), kepala daerah harus memberhentikan pelaksanaan Perda dan selanjutnya DPRD bersama kepala daerah mencabut Perda 
dimaksud. 5)Apabila provinsi/kabupaten/kota - tidak dapat menerima keputusan pembatalan Perda sebagaimana dimaksud pada ayat (3) dengan alasan yang dapat dibenarkan oleh peraturan perundang-undangan, kepala daerah dapat mengajukan keberatan kepada Mahkamah Agung. (6) Apabila keberatan sebagaimana dimaksud pada ayat (5) dikabulkan sebagian atau seluruhnya, putusan Mahkamah Agung tersebut menyatakan Peraturan Presiden menjadi batal dan tidak mempunyai kekuatan hukum. (7) Apabila Pemerintah tidak mengeluarkan Peraturan Presiden untuk membatalkan Perda sebagaimana dimaksud pada ayat (3), Perda dimaksud dinyatakan berlaku

Sedangkan dalam Peraturan Menteri Dalam Negeri Nomor 80 tahun 2015 tentang Pembentukan Produk Hukum Daerah, Menteri Dalam Negeri melakukan evaluasi rancangan perda provinsi dan Gubernur melakukan evaluasi rancangan perda kabupaten/kota sesuai dengan, Undangundang di bidang pemerintahan daerah dan peraturan perundang-undangan lainnya. Proses evaluasi rancangan perda sesuai dengan Undang-Undang di bidang pemerintahan daerah tersebut terdiri atas: RPJPD, RPJMD, APBD, perubahan APBD, pertanggungjawaban pelaksanaan APBD, pajak daerah, retribusi daerah; dan tata ruang daerah.

\section{Instrumen Simplikasi Regulasi sebagai Sistem Reformasi Regulasi Ideal}

Berdasarkan tujuannya, maka Simplifikasi Regulasi bertujuan untuk : a)mewujudkan regulasi yang sederhana dan tertib; b)mewujudkan sistem regulasi yang sederhana dan proporsional; c).Meningkatkan compliance rate (Sadiawati, Dani : 2013). Simplifikasi Regulasi merupakan penyederhanaan regulasi, yaitu suatu cara untuk mengendalikan kuantitas terhadap regulasi yang sedang menjadi hukum positif (sedang berlaku) dalam rangka mewujudkan regulasi yang proporsional. (Strategi Nasional Reformasi Regulasi, Kementrian PPN/Bappenas, 2015:37). Selanjutnya disebutkan bahwa simplifikasi regulasi diawali dengan melakukan beberapa tahapan yaitu sebagai berikut : a).Tahap inventarisasi dan klasifikasi regulasi mengenai bidang tertentu dan regulasi lain yang terkait dengan bidang tersebut; b).Tahap identifikasi terhadap permasalahan atau potensi masalah yang terdapat di dalam regulasi tersebut, termasuk pemangku kepentingan dari regulasi tersebut, permasalahan dapat diidentifikasi seperti permasalahan regulasi yang bersifat konflik, inkonsisten, multitafsir dan tidak operasional; c)Tahap Evaluasi Regulasi dengan menggunakan kriteria Legalitas, Kebutuhan dan Situasional.

Progres simplifikasi regulasi pada tahun 2016 lalu, pemerintah sudah mulai melakukan simplifikasi regulasi. Staf Ahli Menteri Perencanaan Pembangunan Nasional (PPN/Bappenas) Bidang Hubungan Kelembagaan, Diani Sadiawati, mengatakan bahwa simplifikasi regulasi di bidang perizinan dan investasi dilakukan dengan cara berkoordinasi dengan 20 kementerian/lembaga. Pemilihan $20 \mathrm{~K} / \mathrm{L}$ ini didasarkan pada Instruksi Presiden tentang Pelaksanaan Pelayanan Terpadu Satu Pintu Pusat di Badan Koordinasi Penanaman Modal (BKPM). Untuk tahun 2016, 324 regulasi telah dicabut dan sebanyak 75 regulasi direvisi. www.Hukumonline, 18 April 2017 (diakses pada tanggal 16 November 2017)

Regulasi yang sudah disimplifikasi oleh pemerintah dengan Bappenas selaku koordinator pelaksanaan simplifikasi regulasi adalah 61 Perka BKPM yang sudah dicabut dan 4 Perka BPOM direvisi untuk menyederhanakan prosedur dan registrasi. Selanjutnya, revisi 5 Perka BSN untuk menyempurnakan cara penyampaian pengaduan masyarakat serta pengaturan pengembangan SNI, mencabut 22 Permen ATR dan merevisi 3 Permen ATR. Sebanyak 5 Permen, 1 Kepmen, 1 Perdirjen Kelautan dan Perikanan dicabut, dan melakukan revisi 
terhadap 3 Permen Kelautan dan Perikanan untuk mempermudah perizinan dan investasi serta menjamin keberlanjutan usaha nelayan. Selain itu, sebanyak 1 Permen Kesehatan dicabut dengan tujuan untuk memperbaiki layanan dan 12 Permen Ketenagakerjaan juga dicabut guna meningkatkan pelayanan dan mengakomodasi penepatan tenaga kerja sesuai kebutuhan di lapangan.

Regulasi di bidang keuangan juga tak luput dari simplifikasi regulasi. Sebanyak 43 Permen dan Kepmen Keuangan dicabut, serta melakukan revisi terhadap 1 Permen Keuangan. Hal ini dilakukan guna memberikan kepastian hukum dan kemudahan prosedur dalam penetapan tariff dan nilai pabean. Untuk Kementerian Komunikasi dan Informatika, sebanyak 4 Permen sudah dicabut. Tujuannya lebih ditekankan untuk perbaikan dan kemudahan pelayanan serta melindungi kepentingan publik dan atau pengguna. Bidang Lingkungan Hidup, sebanyak 10 Permen LHK sudah dicabut dan merevisi 3 Permen LHK dengan tujuan mempermudah perizinan pemanfaatan hutan. Sebanyak 17 Permen di bidang Pariwisata juga sudah dinyatakan tidak berlaku, dan pencabutan bertujuan untuk menyederhanakan prosedur pengaturan pendaftaran usaha agar proses lebih cepat dan lokasi pelayanan lebih mudah dijangkau. Selanjutnya sebanyak 8 Permen PUPR dicabut dan 3 Permen PUPR direvisi dengan tujuan untuk memudahkan proses perizinan dan investasi dalam bidang jasa konstruksi.

Di bidang pendidikan, sebanyak 128 Permendikbud dicabut dan merevisi 24 Permendikbud. Hal ini dilakukan bertujuan untuk mempermudah perizinan bagi tenaga pendidik dan lembaga pendidik dalam melakukan kegiatan belajar mengajar. Kemudian sebanyak 6 Permen Perdagangan dicabut untuk mempermudah perizinan impor besi baja dan prosedur ekspor produk kehutanan. Kemudian 3 Permen Perhubungan juga dicabut dan sebanyak 5 Permen Perhubungan direvisi untuk mempercepat proses perizinan penggunaan kapal asing untuk kegiatan yang tidak termasuk mengangkut penumpang dan/atau barang yang semula 14 hari kerja menjadi 7 hari kerja. Sedangkan di sektor Perindustrian, sebanyak 19 Permen direvisi guna memberikan kemudahan impor barang sejenis yang sebenarnya tidak terkena kewajiban memenuhi standar SNI. Dan sebanyak 2 Permen di bidang pertanian dicabut dan merevisi 1 Permen Pertanian tentang pemasukan daging, pemasukan sapi, dan pedoman perizinan usaha perkebunan.

Di samping melakukan sejumlah pencabutan dan revisi di berbagai Kementerian/lembaga, di tahun 2016 pemerintah juga membuat rencana revisi beberapa Permen, seperti revisi 2 Permen BUMN tentang tata cara pengangkatan direksi, dewan komisaris, dan dewan pengawas BUMN, rencana revisi Permen ESDM tentang izin usaha bidang pertambangan mineral dan batubara serta minyak dan gas bumi, serta rencana penerbitan Permen Hukum dan HAM tentang permohonan perdaftaran merek. Selain pembatalan dan revisi sejumlah regulasi, beberapa Kementerian juga melakukan simplifikasi regulasi seperti Kementerian Koordinator Bidang Perekonomian (Menko) yang telah melakukan 204 deregulasi melalui sejumlah paket kebijakan meliputi pencabutan, revisi, dan pembentukan regulasi baru. Kementerian Dalam Negeri juga melakukan pembatalan 3.143 regulasi yang terdiri dari Peraturan dan Keputusan Menteri Dalam Negeri serta Peraturan Daerah yang bertentangan dengan peraturan yang lebih tinggi, kepetingan umum, dan/atau kesusilaan serta menghambat investasi. Lalu, Kementerian Hukum dan HAM, melalui agenda reformasi hukum yang meliputi penataan regulasi dengan penguatan pembentukan peraturan perundang-undangan, revitalisasi evaluasi peratuan perundangundangan, serta penataan database peraturan perundang-undangan. Dan berikut adalah data capaian Kementrian/Lembaga yang telah 
melaksanakan simplifikasi regulasi pada tahun 2016.

\begin{tabular}{|c|c|}
\hline $\begin{array}{c}\text { Capaian } \\
\text { Kementrian/Lembaga } \\
\text { dalam Simplifikasi } \\
\text { Regulasi tahun } 2016\end{array}$ & Tujuan \\
\hline $\begin{array}{l}\text { 1. Mencabut } 61 \text { Perka } \\
\text { BKPM yang sudah } \\
\text { tidak digunakan lagi }\end{array}$ & \\
\hline $\begin{array}{lll}\text { 2. } & \text { Mencabut } 6 & \text { Perka } \\
\text { BPOM } & & \\
\text { 3. } & \text { Merevisi } 4 & \text { Perka } \\
\text { BPOM } & & \\
\end{array}$ & $\begin{array}{l}\text { Untuk } \\
\text { menyederhanakan } \\
\text { prosedur registrasi } \\
\text { obat }\end{array}$ \\
\hline $\begin{array}{l}\text { 4. Merevisi } 5 \text { Perka } \\
\text { BSN }\end{array}$ & $\begin{array}{l}\text { Untuk } \\
\text { menyempurnakan } \\
\text { cara penyampaian } \\
\text { pengaduan } \\
\text { masyarakat serta } \\
\text { pengaturan } \\
\text { pengembangan } \\
\text { SNI }\end{array}$ \\
\hline 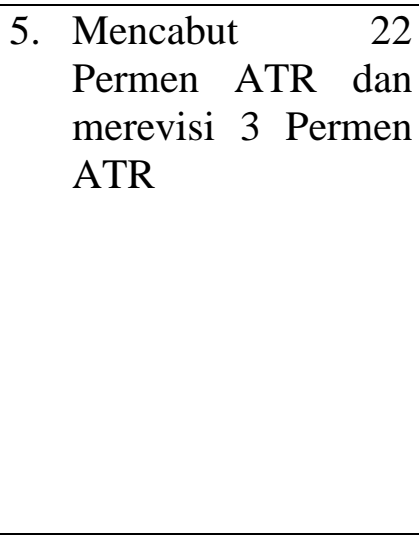 & $\begin{array}{l}\text { Simplifikasi } \\
\text { bertujuan untuk } \\
\text { menjamin hak } \\
\text { masyarakat } \\
\text { hukum adat, } \\
\text { menangani } \\
\text { permasalahan } \\
\text { pertanahan, dan } \\
\text { mempercepat } \\
\text { proses pendaftaran } \\
\text { tanah lengkap }\end{array}$ \\
\hline $\begin{array}{l}\text { 6. Rencana revisi } \\
\text { Permen ESDM } \\
\text { tentang izin usaha } \\
\text { bidang } \\
\text { pertambangan } \\
\text { mineral dan batu } \\
\text { bara serta minyak } \\
\text { dan gas bumi } \\
\end{array}$ & \\
\hline $\begin{array}{ll}\text { 7. } & \text { Mencabut } \\
\text { Permen } & \\
\text { Ketenagakerjaan } & \end{array}$ & $\begin{array}{l}\text { Simplifikasi } \\
\text { bertujuan } \\
\text { meningkatkan } \\
\text { pelayanan dan } \\
\text { mengakomodasi } \\
\text { penempatan } \\
\text { tenaga kerja sesuai } \\
\text { kebutuhan di }\end{array}$ \\
\hline
\end{tabular}

\begin{tabular}{|c|c|}
\hline & lapangan \\
\hline $\begin{array}{l}\text { 8. Rencana penerbitan } \\
\text { Permen Hukum dan } \\
\text { HAM tentang } \\
\text { permohonan } \\
\text { pendaftaran merk }\end{array}$ & \\
\hline 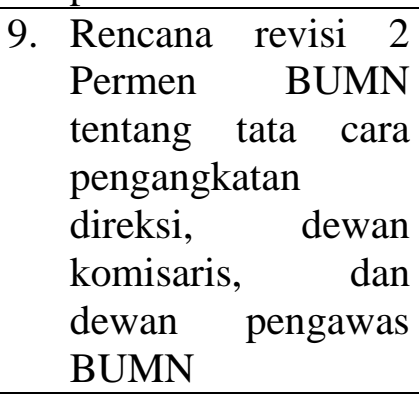 & \\
\hline $\begin{array}{l}\text { 10. Mencabut } 1 \text { Permen } \\
\text { Kesehatan }\end{array}$ & $\begin{array}{l}\text { Simplifikasi } \\
\text { bertujuan untuk } \\
\text { memperbaiki } \\
\text { layanan }\end{array}$ \\
\hline $\begin{array}{l}\text { 11. Mencabut } 6 \text { Permen } \\
\text { Kelautan dan } \\
\text { Perikanan }\end{array}$ & $\begin{array}{l}\text { Merevisi } \\
\text { Permen Kelautan } \\
\text { dan Perikanan } \\
\text { untuk } \\
\text { mempermudah } \\
\text { perizinan dan } \\
\text { investasi serta } \\
\text { menjamin } \\
\text { keberlanjutan } \\
\text { usaha nelayan }\end{array}$ \\
\hline $\begin{array}{l}\text { 12. Mencabut } 3 \text { Permen } \\
\text { Perhubungan dan } \\
\text { merevisi } 5 \text { Permen } \\
\text { Perhubungan }\end{array}$ & $\begin{array}{l}\text { Simplifikasi } \\
\text { bertujuan untuk } \\
\text { mempercepat } \\
\text { proses perizinan } \\
\text { penggunaan kapal } \\
\text { asing untuk } \\
\text { kegiatan yang } \\
\text { tidak termasuk } \\
\text { mengangkut } \\
\text { penumpang } \\
\text { dan/atau barang } \\
\text { yang semula } 14 \\
\text { hari kerja menjadi } \\
7 \text { hari kerja }\end{array}$ \\
\hline $\begin{array}{l}\text { 13. Mencabut } 43 \\
\text { Permen dan } \\
\text { Kepmen Keuangan } \\
\text { serta merevisi } 1\end{array}$ & $\begin{array}{l}\text { Simplifikasi } \\
\text { bertujuan untuk } \\
\text { memberikan } \\
\text { kepastian hukum }\end{array}$ \\
\hline
\end{tabular}




\begin{tabular}{|c|c|}
\hline Permen Keuangan & $\begin{array}{lr}\text { dan } & \text { kemudahan } \\
\text { prosedur dalam } \\
\text { penetapan tarif } \\
\text { dan nilai pabean }\end{array}$ \\
\hline $\begin{array}{l}\text { 14. Mencabut } \\
\text { Permen LHK dan } \\
\text { merevisi } 2 \text { Permen } \\
\text { LHK }\end{array}$ & $\begin{array}{l}\text { Simplifikasi } \\
\text { bertujuan untuk } \\
\text { mempermudah } \\
\text { proses perizinan } \\
\text { pemanfaatan } \\
\text { hutan }\end{array}$ \\
\hline $\begin{array}{l}\text { 15. Mencabut } 17 \\
\text { Permen Pariwisata }\end{array}$ & $\begin{array}{l}\text { Pencabutan } \\
\text { bertujuan untuk } \\
\text { menyederhanakan } \\
\text { prosedur } \\
\text { pengaturan } \\
\text { pendaftaran usaha } \\
\text { (proses lebih cepat } \\
\text { dan lokasi } \\
\text { pelayanan lebih } \\
\text { mudah dijangkau) }\end{array}$ \\
\hline $\begin{array}{lr}\text { 16. Mencabut } & 128 \\
\text { Permendikbud } & \text { dan } \\
\text { merevisi } & 24 \\
\text { Permendikbud } & \end{array}$ & $\begin{array}{l}\text { Simplifikasi } \\
\text { bertujuan untuk } \\
\text { mempermudah } \\
\text { perizinan bagi } \\
\text { tenaga pendidik } \\
\text { dan lembaga } \\
\text { pendidik dalam } \\
\text { melakukan } \\
\begin{array}{l}\text { kegiatan belajar } \\
\text { mengajar }\end{array}\end{array}$ \\
\hline $\begin{array}{lr}\text { 17. Mencabut } & \text { Permen } \\
\text { Pertanian } & \text { dan } \\
\text { merevisi } 1 & \text { Permen } \\
\text { Pertanian } & \text { tentang } \\
\text { pemasukan } & \text { daging, } \\
\text { pemasukan } & \text { sapi, } \\
\text { dan pedoman } \\
\text { perizinan } & \text { usaha } \\
\text { perkebunan } & \\
\end{array}$ & \\
\hline $\begin{array}{l}\text { 18. Mencabut } 6 \text { Permen } \\
\text { Perdagangan }\end{array}$ & $\begin{array}{l}\text { Pencabutan } \\
\text { bertujuan untuk } \\
\text { mempermudah } \\
\text { perizinan impor } \\
\text { besi baja dan } \\
\text { prosedur ekspor } \\
\text { produk kehutanan }\end{array}$ \\
\hline $\begin{array}{l}\text { 19. Mencabut } 8 \text { Permen } \\
\text { PUPR dan revisi } 3\end{array}$ & $\begin{array}{l}\text { Simplifikasi } \\
\text { bertujuan untuk }\end{array}$ \\
\hline
\end{tabular}

\begin{tabular}{|l|l|}
\hline Permen PUPR & $\begin{array}{l}\text { memudahkan } \\
\text { proses perizinan } \\
\text { dan investasi } \\
\text { dalam bidang jasa } \\
\text { konstruksi }\end{array}$ \\
\hline $\begin{array}{l}\text { 20. Mencabut 4 Permen } \\
\text { Komunikasi dan } \\
\text { informatika }\end{array}$ & $\begin{array}{l}\text { Simplifikasi } \\
\text { ditekankan pada } \\
\text { perbaikan dan } \\
\text { kemudahan } \\
\text { pelayanan serta } \\
\text { melindungi } \\
\text { kepentingan } \\
\text { publik dan/atau } \\
\text { pengguna }\end{array}$ \\
\hline $\begin{array}{l}\text { Perindustrian untuk } \\
\text { memberikan }\end{array}$ & \\
kemudahan impor \\
barang sejenis yang \\
sebenarnya tidak \\
terkena kewajiban \\
memenuhi standar \\
SNI : http://www.hukumonline.com, \\
Sumber : \\
2016.
\end{tabular}

Sedangkan untuk tingkat daerah, terdapat berbagai alasan penyebab dibatalkan dan dicabutnya peraturan daerah, seperti kewenangan yang dialihkan dan berubah dari kabupaten/kota ke provinsi seperti Perda Nomor 7/2011 tentang Pengelolaan Pertambangan, Perda Nomor 5/2011 tentang Pengelolaan Air Tanah, dan Perda Nomor 18/2017 tentang Penyelenggaraan Pendidikan di Kabupaten Serang. Selanjutnya Perda Nomor 18/2017 tentang Penyelenggaraan Pendidikan di Kabupaten Serang juga dicabut karena kewenangannya sudah berubah dari kewenangan pemerintah kabupaten menjadi kewenangan pemerintah Provinsi Banten. Capaian simplifikasi regulasi di tingkat pusat dan daerah tersebut sejalan dengan arah kebijakan pembangunan bidang regulasi 2015-2019 yaitu mewujudkan sinergitas antara kebijakan dan regulasi agar tercipta sistem regulasi nasional yang sederhana dan tertib dalam rangka mendukung pembangunan keunggulan komparatif 
perekonomian yang berbasis sumber daya alam yang tersedia, sumber daya manusia yang berkualitas serta kemampuan Iptek sehingga simplifikasi regulasi sebagai instrumen reformasi regulasi dapat terwujud secara ideal dalam mendukung proses pembangunan bidang regulasi secara nasional.

\section{PENUTUP}

Instrumen Simplifikasi Regulasi sebagai formulasi yuridis dalam strategi penataan kebijakan regulasi bertujuan untuk mewujudkan regulasi yang tertib dan sederhana melalui proses review dan rekonstruksi regulasi yang ada berdasarkan kriteria legalitas dan kebutuhan untuk selanjutnya diberikan rekomendasi alternatif tindakan regulasi untuk dipertahankan, direvisi atau dicabut. Peraturan Daerah sebagai peraturan perundang-undangan berskala lokal merupakan bagian dari locus simplifikasi regulasi, hal tersebut dikarenakan masih terjadinya disharmonis regulasi di Indonesia seperti kualitas yang masih buruk dari segi konten dan substansi, kuantitas regulasi yang tidak terkontrol, tidak adanya kewenangan atau otoritas tunggal pengelola regulasi dan kurangnya pemahaman merupakan beberapa problem regulasi yang terjadi.

Reformasi regulasi melalui simplifikasi regulasi merupakan salah satu opsi yang tepat dalam rangka menciptakan tatanan regulasi yang tertib dan harmonis, sebuah regulasi idealnya tidak boleh bertentangan dengan regulasi yang setara dan tidak boleh juga bertentangan dengan regulasi di atasnya. Harmonisasi regulasi dengan tujuan kualitas, mendukung dinamika sosial secara tertib, terselenggaranya penyelenggara negara yang efektif dan efisien dan memuat aturan yang tertib dan sederhana merupakan prasyarat pembentukan sebuah regulasi yang ideal ideal

\section{DAFTAR PUSTAKA}

Asshiddiqie, Jimly, 2006, Teori Hans Kelsen Tentang Hukum, Jakarta, Sekretariat Jenderal dan Kepaniteraan Mahkamah Konstitusi RI.

Deputi Politik, hukum, Pertahanan dan Keamanan, serial Multilateral Meeting II, 2016

Ibnu Sina Chandranegara, 2014, artikel yang berjudul : Menemukan Formulasi Diet Regulasi, Wakil Dekan Fakultas Hukum Universitas Muhammadiyah Jakarta, Dosen Tetap di bawah Departemen Hukum Tata Negara, Hukum Administrasi Negara dan Hukum Internasional. Sekretaris Majelis Hukum dan HAM PP Muhammadiyah, Anggota Asosiasi Pengajar Hukum Acara Mahkamah Konstitusi, dan Anggota Asosiasi Pengajar HTN-HAN

Kementerian Hukum dan Hak Asasi Manusia, Pengharmonisasian, Pembulatan, dan Pemantapan, Konsepsi Rancangan Peraturan, Perundang-Undangan. (Jakarta: Direktorat Jenderal Peraturan PerundangUndangan, 2010) hlm 18-20

Komite Pemantauan Pelaksanaan Otonomi Daerah, Panduan Pembuatan Kebijakan (Perda Ramah Investasi) bekerjasama dengan FordFoundation, 2013

Maharani Sukma Novira, Maret 2017. Analisis Yuridis Pembatalan Perda oleh Menteri Dalam Negeri, Jurnal Hukum Universitas Diponegoro, Volume 5 Nomor 1, hal 1-21.

Minolah, Maret 2011. Tinjauan Yuridis terhadap Pembatalan Peraturan Daerah Provinsi di Indonesia, Jurnal Syiar Hukum, Universitas Islam Bandung, Volume XIII Nomor 1, hal 1-15 
Peraturan Menteri Dalam Negeri Nomor 80 tahun 2015 tentang Pembentukan Produk Hukum Daerah

Sadiawati, Diani. Rekonseptualisasi

Pembentukan Regulasi. Makalah disampaikan dalam Konsultasi Publik Reformasi Regulasi Di Indonesia, Hotel Grand Melia, Jakarta, 15 Juli 2013.

Strategi Nasional Reformasi Regulasi, 2015. Kementrian PPN/Bappenas Republik Indonesia

Undang-undang Dasar 1945

Undang-undang Nomor 32 Tahun 2004

tentang Pemerintahan Daerah

UU Nomor 12 Tahun 2011 tentang Pembentukan Peraturan Perundang-undangan.

www.hukumonline.com, capaian simplifikasi regulasi, (diakses pada tanggal 18 April 2017)

www.negarahukum. Artikel Damang, SH, MH (diakses pada tanggal 15 November 2017). 